\title{
Recent observations on leptospirosis in Northern Ireland and their bearing on current diagnostic methods
}

\author{
T. S. WILSON \\ From The Laboratories, Belfast City Hospital, Belfast
}

SYNOPSIS An investigation was undertaken to assess the present importance of leptospiral infections in Northern Ireland, and in particular to look for evidence of infection by leptospiral serotypes other than L. icterohaemorrhagiae and L. canicola.

Blood samples from 335 patients, sent to the laboratory for a variety of tests, were examined. After initial screening with five groups of pooled antigens, tests for leptospiral agglutinins were completed with formolized antigens prepared from 13 different serotypes. In seven patients a diagnosis of acute leptospirosis was made while nine others showed serological evidence of previous leptospiral infection. Attempts to isolate leptospirae by culture from 29 blood samples were unsuccessful.

The serological results indicate that two additional leptospiral serotypes, namely L. ballum and L. bratislava, are causing human infection in Northern Ireland, and presumably also in other parts of the British Isles. Some clinical and epidemiological features associated with different types of leptospiral infection are described. It is stressed that leptospirosis is essentially a febrile illness, that meningeal symptoms are common, and that (contrary to popular belief) jaundice is by no means a constant occurrence.

The implications of these findings are discussed, with special reference to the diagnosis of leptospiral infections. Laboratory diagnostic procedures are briefly reviewed, and the possible deficiencies of the agglutination test commonly used in Britain are pointed out. Some suggestions are made concerning both clinical and laboratory aspects of diagnosis, and the need for a reliable screening test for all forms of leptospiral infection is emphasized.

Leptospirosis is one of the zoonoses, and a wide variety of animals may act as carriers of leptospirae, the organisms multiplying in their kidneys and being excreted in the urine. Human infection usually follows contact with contaminated water, soil, or other material; infection by direct contact with a carrier host is less common. Recent surveys in other countries have indicated that leptospiral infections of rodents and many other animals, both wild and domestic, are much more widespread than was formerly appreciated, and that infection in man may often not be recognized.

The leptospirae are classified on the basis of their antigenic characters, using the criteria proposed by Wolff and Broom (1954). Sixty serotypes and sub-

${ }^{1}$ Present address: Department of Microbiology, Queens University of Belfast, Grosvenor Road, Belfast 12.

Received for publication 10 June 1966. serotypes were listed by a W.H.O./F.A.O. expert committee on zoonoses (Report, 1959), and more recent discoveries bring the total to about 100 (Memorandum, 1965). Some serotypes, such as Leptospira icterohaemorrhagiae and $L$. canicola, are almost universal in their distribution, while others have only been found in certain localized areas. The presence or absence of suitable carrier hosts probably plays an important part in determining the geographical distribution of different leptospiral serotypes (Alston and Broom, 1958).

The first confirmed case of human leptospiral infection in Britain, due to L. icterohaemorrhagiae, was described by Manson-Bahr, Wenyon, and Brown (1922). Many other infections with this serotype have been recognized since then, occurring commonly in exposed occupational groups such as miners, farmers, and sewer workers. Baber and Stuart (1946) reported 
the first British case of $L$. canicola infection, and within the next four years another 70 were diagnosed (Broom, 1951). Alston and Broom (1958) stated that no human infections due to serotypes other than $L$. icterohaemorrhagiae and $L$. canicola were known to have occurred in the British Isles (apart from laboratory infections); even since then none seem to have been reported in the literature, though Turner (1963, 1965) has found agglutinins to other serotypes in a small proportion of the human sera he has examined, and the significance of these findings is being investigated.

Until quite recently, $L$. icterohaemorrhagiae and L. canicola were also the only two serotypes which had been found in animals in Britain, although Alston and Broom (1958) were able to list more than a dozen leptospirae which occurred in the adjacent countries of Continental Europe. Commenting on this disparity, they pointed out that various species of rodents which were known to carry serotypes such as $L$. ballum, $L$. bataviae, $L$. sejroe and $L$. grippotyphosa on the Continent were also present in the British Isles.

However, within the last few years the position in Britain has changed considerably. Serological tests have revealed antibodies to $L$. hyos and $L$. pomona in dogs (Davies, 1957), to L. pomona and L. ballum in pigs (Michna, 1958; Davies, 1960), and to $L$. sejroe, L. bataviae, and L. grippotyphosa in several species of rodents (Broom and Coghlan, 1958). In addition, a number of strains of leptospirae have been isolated from small field rodents; some of these strains were identified as $L$. ballum and some as belonging to the $L$. sejroe- $L$. saxkoebing group (Broom and Coghlan, 1958). A further serotype named $L$. bratislava has been isolated from hedgehogs (Broom and Coghlan, 1960; Turner, 1962), and more recently, $L$. erinacei-auriti from a water vole (Slavin, Salt, and Wolff, 1964).

Clearly many more leptospiral serotypes are present in Britain than was suspected a few years ago. Most of these serotypes are known to cause human illness in other countries, and it seemed probable that similar human infections were occurring in the British Isles, but were remaining undiagnosed.

The investigation reported here was designed to look for evidence of such leptospiral infections in Northern Ireland, an area with a large farming community and a known high incidence of Weil's disease (Kennedy, 1953).

\section{MATERIALS AND METHODS}

Thirteen leptospiral serotypes were used as antigens in a series of serological tests which, it was hoped, would detect agglutinins to most leptospirae likely to be en- countered. Tests were carried out by the microscopic 을 agglutination technique, employing formolised lepto- $\vec{F}$ spiral antigens, following in general the methods described by Alston and Broom (1958).

SELECTION OF SEROTYPES FOR TESTS These were chosen on the advice of Turner (1962). Selection was based $\propto$ mainly on the known antigenic grouping of the leptospirae, one member being included from each of the principal serological groups. Where possible the actual. serotype chosen was one which was known, or suspected, $\overrightarrow{\vec{\omega}}$ to be present in the British Isles, taking into account the findings in animals within recent years.

PREPARATION OF ANTIGENS AND ANTIGEN POOLS The $13 \overrightarrow{\vec{c}}$ leptospiral serotypes were maintained in Korthof's or medium, subcultures being performed every seven to $10 \frac{\oplus}{\mathrm{G}}$ days. Antigens were prepared by adding neutralized $F$

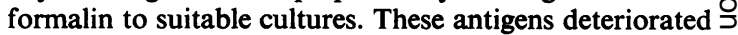
slowly, but most remained satisfactory for at least two $\vec{C}$

weeks, and some for considerably longer. antigens, each pool containing a mixture of two or three $\frac{\mathbb{Q}}{3}$ antigenic suspensions of approximately equal density. 을 Each pool was tested with antiserum against all its con- $\underset{\mathbb{D}}{-}$ stituent antigens, to ensure that all were reacting satis- $\vec{\theta}$ factorily. If necessary, extra quantities of poorly reacting $\mathscr{\odot}$ antigens were added to the pools concerned.

The leptospiral serotypes used in these tests, and the arrangement of the five antigenic pools, are shown in Table I.

\section{TABLE I}

LIST OF LEPTOSPIRAL SEROTYPES AND THEIR ARRANGEMENT IN ANTIGEN POOLS

Serotype (strain) Pool

L. ballum (Castellon 3)

A

L. canicola (Hond Utrecht IV)

L. icterohaemorrhagiae (Coppard)

B

L. javanica (Veldrat Bataviae 46)

L. bataviae (van Tienen)

L. grippotyphosa (Moscow V)

L. pyrogenes (Salinem)

L. autumnalis (Akiyami A)

L. pomona (Pomona)

L. saxkoebing (Mus 24)

L. bratislava $(\mathrm{H} .10)^{1}$

L. hyos hyos (Mitis Johnson)

L. mini mini (Sari)

${ }^{1} L$. bratislava $(\mathrm{Jez})$ later replaced this strain. METHOD OF SEROLOGICAL TESTS These were carried out
in three stages.

1 Preliminary screening All sera were tested at final 0 dilutions of $1 / 50$ and 1/500 against the five antigen pools 0 A, B, C, D, and E. The second dilution was used to avoid $\mathbb{D}$ missing high-titre agglutinating sera, which often show a marked prozone phenomenon. 
2 'Singling' Sera which showed even traces of agglutination with any pool were next tested against the single antigen constituents of the reacting pool or pools, usually at a final serum dilution of $1 / 50$. Occasional sera showing strong reactions with several pools were also 'singled' at higher dilutions, e.g., $1 / 100$ or $1 / 500$.

3 Titration Sera were finally titrated against the single antigens which they had agglutinated. Often titration was only required against one or two antigens. However, marked co-agglutination involving many leptospiral serotypes is often found in the early stages of a leptospiral infection. In such cases titration was only carried out with those antigens which were agglutinated at the higher dilutions in the 'singling' procedure, thus obviating the need to perform a full titration with a large number of antigens.

The titre of the serum against any antigen was taken as the highest serum dilution at which $50 \%$ or more of the leptospirae in the antigen suspension were agglutinated, as suggested by Alston and Broom (1958). The scheme of titration was that described by Schuffner (1934), giving final serum dilutions of $1 / 10,1 / 30,1 / 100,1 / 300,1 / 1,000$, $1 / 3,000$, etc.

Rabbit antisera were used to test the reactivity of each batch of antigen suspensions. Negative controls were included with each set of tests, in order to detect spontaneous agglutination in any antigen, this occurring occasionally for no obvious reason.

ISOLATION OF LEPTOSPIRAE This was attempted in some cases, where fairly fresh blood samples were available. A few drops of blood, or broken-up blood clot in serum, were inoculated into bottles of Korthof's medium. These were incubated at 30 to $32^{\circ} \mathrm{C}$., being examined at intervals over a period of at least six weeks for evidence of leptospiral growth.

SOURCE OF SPECIMENS EXAMINED Blood samples from 335 patients were examined. Sera from 320 of these were obtained from specimens received at The Laboratories, Belfast City Hospital, for a variety of serological tests (see Table II). The 120 specimens for leptospiral agglutination tests represented almost a full year's requests for this examination. Samples for other serological tests were collected at intervals. The period covered was March 1962 to March 1963.

The remaining sera examined were kindly provided by
Dr. J. H. Connolly of the Virus Reference Laboratory, Department of Microbiology, Queen's University, Belfast. These came from 15 patients with aseptic meningitis, in whom virological and other investigations had proved negative.

\section{RESULTS}

CULTURAL RESUlTs Attempts were made to isolate leptospirae from 29 of the 120 blood specimens sent to the laboratory with a request for leptospiral agglutination tests. Presumably these samples were from patients in whom the clinicians considered leptospirosis was a possible diagnosis. No leptospirae were isolated.

SEROLOGICAL RESULTS A summary of the positive serological findings, with their distribution amongst the different groups of sera examined, is shown in Table II. The positive results have been classified under three headings as follows:

Acute leptospirosis Seven patients were considered to show evidence of active leptospiral infection. In five, a significant rise in antibody titre was demonstrated in successive blood samples. The remaining two had agglutinins to a titre of $1 / 100$ in the only blood tested, both patients dying with typical clinical features of severe leptospirosis. Another feature of the serological reactions in most of the acute cases was marked co-agglutination, involving varying numbers of the leptospiral antigens being used. Details of the serological findings in the patients with acute leptospirosis, and of the associated clinical syndromes, are given in Table III.

Past infections Nine patients were regarded as showing serological evidence of previous leptospiral infections, in the form of residual agglutinins which were present to a titre of $1 / 100$ or higher. No rise in titre was demonstrated in later blood samples obtained from seven of these nine patients. The almost complete absence of any co-agglutination was in direct contrast to the findings in the patients with active infections. Details are given in Table IV.

\section{TABLE II}

SOURCE OF SERA TESTED AND DISTRIBUTION OF VARIOUS GROUPS OF POSITIVE FINDINGS

Number of Patients

120

Leptospiral agglutination tests

Miscellaneous serological tests (Widal and Abortus agglutinations, Paul-Bunnell test, etc.)

Wassermann and Kahn

Aseptic meningitis sera for virus studies

Totals

$\begin{array}{rlll}120 & 5(4 \cdot 2 \%) & 5(4 \cdot 2 \%) & 10(8 \cdot 3 \%) \\ 100 & - & 2(2 \%) & 17(17 \%) \\ 100 & - & 2(2 \%) & 14(14 \%) \\ 15 & 2(13 \cdot 3 \%) & - & - \\ 335 & 7(2.1 \%) & 9(2.7 \%) & 41(12 \cdot 2 \%)\end{array}$

Serological Findings Indicating:

\begin{tabular}{lll}
\hline Acute & Past & Low-titre \\
Leptospirosis & Infection & Agglutination
\end{tabular}


TABLE III

SUMMARY OF SEROLOGICAL FINDINGS AND CLINICAL FEATURES IN CASES OF ACUTE LEPTOSPIROSIS

\begin{tabular}{|c|c|c|c|c|c|c|c|c|}
\hline Case & $\operatorname{Sex}$ & Age & Occupation & $\begin{array}{l}\text { Day of } \\
\text { Illness }\end{array}$ & Antigen & Serum Titre & $\begin{array}{l}\text { Probable Infecting } \\
\text { Serotype }\end{array}$ & Clinical Syndrome \\
\hline $\begin{array}{l}\text { Case } 1 \\
\text { (E.M.) }\end{array}$ & $\mathbf{F}$ & 51 & $\begin{array}{l}\text { Factory } \\
\text { worker } \\
\text { and } \\
\text { housewife }\end{array}$ & $\begin{array}{r}7 \\
17 \\
158\end{array}$ & $\begin{array}{l}\text { Canicola } \\
\text { Other serotypes } \\
\text { Canicola } \\
\text { Icterohaemorrhagiae } \\
\text { Other serotypes } \\
\text { Icterohaemorrhagiae }\end{array}$ & $\begin{array}{c}30 \\
\text { Weak reactions }^{1} \\
100 \\
100 \\
\text { Weak reactions }^{1} \\
300\end{array}$ & L. icterohaemorrhagiae & $\begin{array}{l}\text { Mild leptospirosis } \\
\text { with aseptic } \\
\text { meningitis }\end{array}$ \\
\hline $\begin{array}{l}\text { Case } 2 \\
\text { (J.T.M.) }\end{array}$ & $\mathbf{M}$ & 13 & Schoolboy & $\begin{array}{r}7 \\
14 \\
164\end{array}$ & $\begin{array}{l}\text { Several serotypes } \\
\text { Several serotypes } \\
\text { Icterohaemorrhagiae } \\
\text { Canicola }\end{array}$ & $\begin{array}{c}\text { Weak reactions }{ }^{1} \\
\text { Weak reactions }^{1} \\
100 \\
30\end{array}$ & L. icterohaemorrhagiae & $\begin{array}{l}\text { Mild leptospirosis } \\
\text { with meningeal } \\
\text { symptoms }\end{array}$ \\
\hline
\end{tabular}

Possible Sourc్s of Infection

Information $n$ available

available

\begin{tabular}{|c|c|c|c|c|c|c|c|}
\hline $\begin{array}{l}\text { Case } 3 \\
\text { (W.A.) }\end{array}$ & $\mathbf{M}$ & 45 & Lorry driver & 8 & $\begin{array}{l}\text { Icterohaemorrhagiae } \\
\text { Canicola } \\
\text { Bataviae } \\
\text { Pyrogenes } \\
\text { Ballum }\end{array}$ & $\begin{array}{r}100 \\
100 \\
30 \\
30 \\
10\end{array}$ & L. icterohaemorrhagiae \\
\hline Case 4 & $\mathbf{M}$ & 13 & Schoolboy & $\begin{array}{r}6 \\
16\end{array}$ & $\begin{array}{l}\text { Icterohaemorrhagiae } \\
\text { Bratislava } \\
\text { Icterohaemorrhagiae } \\
\text { Bratislava } \\
\text { Canicola } \\
\text { Autumnalis }\end{array}$ & $\begin{array}{r}100 \\
100 \\
1,000 \\
300 \\
100 \\
100\end{array}$ & L. icterohaemorrhagiae \\
\hline $\begin{array}{r}\text { Case } 5 \\
\text { (J.B.) }\end{array}$ & $\mathbf{M}$ & 46 & Bartender & $\begin{array}{r}22 \\
143\end{array}$ & $\begin{array}{l}\text { Bratislava } \\
\text { Icterohaemorrhagiae } \\
\text { Several serotypes } \\
\text { Bratislava } \\
\text { Icterohaemorrhagiae } \\
\text { Canicola } \\
\text { Autumnalis } \\
\text { Several serotypes } \\
\text { Bratislava } \\
\text { Icterohaemorrhagiae } \\
\text { Canicola } \\
\text { Autumnalis } \\
\text { Several serotypes } \\
\text { Bratislava } \\
\text { Icterohaemorrhagiae } \\
\text { Autumnalis }\end{array}$ & $\begin{array}{c}3,000 \\
300 \\
\text { Weak reactions }^{1} \\
30,000 \\
3,000 \\
300 \\
300 \\
\text { Lower titres } \\
100,000 \\
30,000 \\
1,000 \\
300 \\
\text { Lower titres } \\
10,000 \\
10,000 \\
300\end{array}$ & $\begin{array}{l}\text { ? L. bratislava } \\
\text { ? L. icterohaemor- } \\
\text { rhagiae }\end{array}$ \\
\hline $\begin{array}{l}\text { Case } 6 \\
\text { (F.W.) }\end{array}$ & $\mathbf{M}$ & 17 & Breadserver & $\begin{array}{r}5 \\
15\end{array}$ & $\begin{array}{l}\text { Ballum } \\
\text { Canicola } \\
\text { Icterohaemorrhagiae } \\
\text { Ballum } \\
\text { Canicola } \\
\text { Icterohaemorrhagiae } \\
\text { Canicola } \\
\text { Ballum }\end{array}$ & $\begin{array}{r}30 \\
30 \\
30 \\
300 \\
300 \\
100 \\
30 \\
10\end{array}$ & $\begin{array}{l}\text { ? L. canicola } \\
\text { ? L. ballum }\end{array}$ \\
\hline $\begin{array}{c}\text { Case } 7 \\
\text { (R.B.) }\end{array}$ & $\mathbf{M}$ & 79 & $\begin{array}{l}\text { Farmer } \\
\text { (retired) }\end{array}$ & $2^{2}$ & $\begin{array}{l}\text { Bratislava } \\
\text { Canicola } \\
\text { Icterohaemorrhagiae } \\
\text { Autumnalis }\end{array}$ & $\begin{array}{r}100 \\
10 \\
10 \\
10\end{array}$ & Indefinite \\
\hline
\end{tabular}

Severe leptospirosis, Not known with jaundice, haemorrhages, anuria.

Died on day 15

Mild leptospirosis with aseptic available meningitis

Moderately severe Rats seen by leptospirosis with neighbour at the jaundice, haemor- bottem of patient hages, and some garden, in which renal impairment he had recent been workin

Mild leptospirosis with aseptic meningitis
A dog at home which was nơ il

${ }^{1}$ Weak reactions $=$ partial agglutination $(<50 \%)$ at low serum dilutions.

${ }^{2}$ Total duration of illness not known exactly in case 7 . Times given are from date of onset of jaundice.

Low-titre agglutination Sera from 41 patients agglutinated one or more of the leptospiral antigens at dilutions of $1 / 10$ or $1 / 30$. Where second blood samples were obtained no rise in titre was demonstrated.

IDENTITY OF INFECTING SEROTYPES These are shown in Tables III and IV. In several of the acute infections the leptospiral serotype involved could not be accurately identified, due to the degree of coagglutination present.

CLINICAL AND EPIDEMIOLOGICAL DETAILS The information available is summarized in Tables III and 
TABLE IV

SUMMARY OF SEROLOGICAL FINDINGS AND CLINICAL DATA IN CASES WITH EVIDENCE OF PAST INFECTION

\begin{tabular}{|c|c|c|c|c|c|c|c|c|c|c|}
\hline Case & $\operatorname{Sex}$ & Age & Occupation & $\begin{array}{l}\text { Day of } \\
\text { Illness }\end{array}$ & Antigen & $\begin{array}{l}\text { Serum } \\
\text { Titre }\end{array}$ & $\begin{array}{l}\text { Probable Past } \\
\text { Infecting } \\
\text { Serotype }\end{array}$ & $\begin{array}{l}\text { Present or } \\
\text { Recent Illness }\end{array}$ & Past Illnesses & $\begin{array}{l}\text { Possible Source of } \\
\text { Infection }\end{array}$ \\
\hline
\end{tabular}



(J. McG.)

L. ballum

previously-prob-

- cottage: rats,

hepatitis. 'Rat-

mice, and other

bite' fever 10 years

animals about

previously after

working in rat-

infested field

$\begin{array}{ccrlrlr}\begin{array}{c}\text { Case 9 } \\ \text { (J.B.) }\end{array} & \text { M } & 66 & \text { Farmer } & 7 & \begin{array}{l}\text { Ballum } \\ \text { Bratislava }\end{array} & 300 \\ \text { Ballum } & 100 \\ \begin{array}{c}\text { Case 10 } \\ \text { (H.C.) }\end{array} & \text { M } & 53 & \text { Labourer } & 21 & \text { Ballum } & 100 \\ \text { Ballum } & 154 & 100\end{array}$

300 L. ballum

10

Infective hepatitis

Influenza one year previously

Rats, mice, and other farm animals

100 L. ballum

100

Brucellosis
illness

Was bitten on

finger by a rat about 10 years previously. Also rats around old house

Case $11 \quad M \quad 50+$ Farmer

(R.L.)

7 Ballum

45 Canicola

100

L. ballum

Ballum

? Wernicke's encephalopathy

Jaundice in childhood. Severe influenza many

Lives in very poo farm cottage: rats, mice, and other animals years ago about

Case 12

$$
\text { M } 45 \quad \text { Farmer }
$$

60 Ballum

100

L. ballum

Severe 'influenza' two months

Previous attacks of Rats, mice, and previously treated with tetracyclines

Case 13 M $46 \quad$ Carpenter

3 Ballum

100

L. ballum

Acute epididymoorchitis, following 'influenza' about 5 weeks previously which was treated with tetracyclines

$\begin{array}{llll}\text { Case } 14 & \text { M } & 28 & \text { Farmer }\end{array}$

23

Icterohaemor rhagiae Bratislava Icterohaem 340 Bratislava Icterohaemor- $\quad 30$ rhagiae

Case 15

(T.W.)

Case 16 (D.A.)

$\begin{array}{llr}23 & \text { Bratislava } & 100 \\ & \text { Icterohaemor- } & 10 \\ \text { rhagiae } & \text { Bratislava } & 100 \\ & \begin{array}{l}\text { Icterohaemor- } \\ \text { rhagiae }\end{array} & 30 \\ & & \end{array}$

$\begin{array}{lll}\text { M } 54 & \begin{array}{l}\text { Long-term } \\ \text { mental } \\ \text { patient. Ex } \\ \text { farm worker }\end{array} \\ M & 38 \quad & \text { Draughtsman }\end{array}$

IV, including a note of possibly relevant previous illnesses in the group of patients with serological evidence of past infection.

\section{DISCUSSION}

CULTURAL ResUlts Attempts to isolate leptospirae in Korthof's medium failed with 29 of the blood specimens received with a request for leptospiral agglutination tests; these included five out of the seven patients later diagnosed serologically as acute leptospirosis. Analysis revealed that, with one 
have been a contributory cause in some instances, as may the fact that some of the patients were on antibiotic therapy when the blood samples were taken.

SEROLOGICAL RESULTS These are discussed under the three headings defined earlier.

Acute leptospirosis In the absence of an isolation, the difficulty in identifying the infecting serotype by serological tests is well illustrated in Table III. Early in the illness coagglutination is marked, and heterologous agglutinins may actually be present to a higher titre than the homologous agglutinins, the 'paradoxical reaction' described by Fuhner (1950) and others. After reaching a peak, however, the titres of the heterologous agglutinins usually fall rapidly, whereas the homologous agglutinin titre may continue to rise for a short period and then declines more slowly and may remain at a level of $1 / 100$ or $1 / 300$ for many years (Wolff, 1954).

Where this differential fall in titre is not sufficiently clear cut, as in cases 5 and 6 in Table III, absorption tests might help to determine the infecting serotype. Unfortunately these could not be carried out during this investigation.

A further obstacle to serological diagnosis is the effect of early therapy with antibiotics, which may delay the appearance of agglutinins and prevent them reaching a high titre (Wolff, 1954; Babudieri, 1961). Case 2 in Table III may have been an example of this effect, since penicillin and sulphadimidine were given from the onset of illness.

Past infections The antibody titre accepted as indicative of previous leptospiral infection has varied with different authors. General opinion now seems to be that a titre of 1/100 may be regarded as significant. This was the level suggested by a World Health Organization expert study group for the microscopic agglutination test, using either living or killed antigen (Report, 1955), and it was adopted for this investigation, though many workers would accept a lower titre when formolised antigens are used.

On this basis, sera from nine patients out of 335 $(2.7 \%)$ were regarded as showing evidence of past leptospiral infection. Although the patients to some extent formed selected groups and are unlikely to be representative of the population as a whole, the fairly uniform distribution of these residual antibodies among the different groups of sera examined (see Table II) does suggest that leptospiral infections may be more common than is generally appreciated. Indeed the findings in case 6 (Table III) in which the titre had fallen to $1 / 30$ within 10 months of the acute infection, suggest that a critical level of $1 / 100$ may underestimate the position, and that some sera here classified in the low-titre agglutination group may in fact have contained residual antibodies. Wolff (1954) noted that in some patients the agglutinin titre may fall to zero within a year of the infection.

Low-titre agglutination Most of the sera placed in this group reacted with only one antigen. Three sera, all from country dwellers, agglutinated $L$. ballum to a titre of $1 / 30$, and these may possibly have contained true residual antibodies from past infections. A few other sera showed low-titre agglutination with two or more antigens, almost certainly non-specific in nature. Two very jaundiced sera agglutinated a wide range of antigens at dilutions of $1 / 10$ or $1 / 30$; the significance of this is not clear.

INFECTING SEROTYPE AND CLINICAL SYNDROME A comparison of Table III with Table IV shows that whereas L icterohaemorrhagiae was probably responsible for four, perhaps five, of the seven acute infections, it was concerned in only one out of nine of the past infection group. Infections with this serotype often present the classical clinical picture of severe leptospirosis as described by Weil (1886), with fever, jaundice, haemorrhages and varying degrees of renal impairment. However, milder infections due to $L$. icterohaemorrhagiae are quite common, and jaundice is by no means a constant feature; indeed, where observations are not confined to severely ill hospital patients, it may be present in less than $40 \%$ of diagnosed infections (Walch-Sorgdrager, 1939; and see Table III). In the milder clinical syndromes, sometimes termed 'benign leptospirosis', meningeal symptoms or a frank aseptic meningitis frequently occur; these findings were prominent in the present group of acute infections (see Table III).

Most of the other leptospiral serotypes usually give rise to illnesses of the 'benign leptospirosis' type. Fever, profuse sweating, headache, and muscular tenderness are common features (Alston and Broom, 1958). Meningeal involvement occurs in a number of patients, but jaundice is comparatively rare; if both these features are absent, the infections can only be differentiated from other acute febrile illnesses such as influenza by appropriate laboratory tests.

In the present investigation, $L$. ballum seems to have been associated with at most one of the seven acute infections, while antibodies to it were found in six of the nine 'past infection' group. The probable explanation for this discrepancy is either that the acute illness due to this serotype is mild, or that the clinical picture does not suggest leptospirosis to the doctor in attendance, so that the necessary laboratory investigations are not requested. Reports from other countries suggest that $L$. ballum infections conform in general to the syndrome of benign leptospirosis, with fever, headache, and muscular pains; a common complication has been the development 
of orchitis, usually during convalescence (Stoenner and Maclean, 1958; Boak, Linscott, and Bodfish, 1960; Kappeler, Barandun, Luthi, and Wiesmann, 1961). Three of the six 'past infection' patients had histories of possibly relevant acute febrile illnesses (cases 8, 12, and 13, Table IV), while one (case 13) had subsequently developed an acute epididymoorchitis; these illnesses may have been $L$. ballum infections.

L. canicola and $L$. bratislava were probably each responsible for one of the acute infections, and antibodies to $L$. bratislava were present in two of the nine 'past infection' patients. $L$. canicola is well known as a cause of one of the milder forms of leptospirosis, frequently presenting as an aseptic meningitis (see case 6); it requires no further mention.

I have not been able to find any details of human infections with $L$. bratislava in the literature, apart from one febrile patient in Queensland from whom strain esposito was isolated (Smith and Brown, 1955); this strain was later shown to be identical with L. bratislava (Kmety, 1960). Case 5, which was possibly due to this serotype, was of moderate severity with deep jaundice, and, in the absence of serological testing with multiple antigens, would have been regarded as a typical case of Weil's disease with a rising titre of antibodies to $L$. icterohaemorrhagiae. Case 14 gave a history of aseptic meningitis about nine years previously, which in retrospect may have been leptospiral in origin. It thus seems probable that $L$. bratislava infections resemble those caused by other leptospiral serotypes.

EPIDEMIOLOGICAL FEATURES Information about possible sources of infection was not available from the one woman among the 16 patients listed in Tables III and IV, nor from three of the 15 men. Seven of the remaining 12 were farmers or general labourers, and all had possible contact with rats, other rodents, or domestic animals which are known to harbour leptospirae. $L$. ballum has been isolated from various species of mice and other field rodents (BorgPetersen, 1944; Yager, Gochenour, Alexander, and Wetmore, 1953; Broom and Coghlan, 1958) and from rats (Humphreys, Campbell, and Smith, 1953; Covaleda, Pumarola, and Cantarell, 1953). Antibodies to this serotype have been detected in a number of domestic animals, including pigs (Davies, 1960) and dogs (Alexander, Gleiser, Malnati, and Yoder, 1957). Hedgehogs seem to be the principal carriers of L. bratislava in Europe (Kmety, 1954; Plesko, Bakoss, Kmety, and Vachold, 1960) and in the British Isles (Broom and Coghlan, 1960; Turner, 1963). The predominantly rural connexions of the persons infected by these two serotypes is therefore not unexpected (see Table IV).
L. icterohaemorrhagiae infections are probably usually acquired from rats, though dogs and many other animals may also carry this serotype (Alston and Broom, 1958). L. canicola is relatively common in dogs (Broom and MacIntyre, 1948) and also in pigs (Coghlan, Norval, and Seiler, 1957). Rats and dogs are found in urban as well as rural areas, so infections with these two serotypes do not tend to be restricted to farmers and other country dwellers. Although bathing in infected ponds, canals, and streams is a common method of acquiring infection with L. icterohaemorrhagiae, particularly in Holland (Walch-Sorgdrager, 1939), only the schoolboy (case 2, Table II) seems to have been infected in this way.

COMMENT ON DIAGNOSTIC METHODS Many different laboratory procedures have been used for the diagnosis of leptospirosis. They fall into three main groups:

1 Direct microscopic examination of blood or other body fluids or tissues (stained or unstained).

2 Isolation of leptospirae in culture media or by animal inoculation.

3 Serological tests, of which a considerable variety have been devised.

Most laboratories in the British Isles appear to depend on serological results for diagnosing leptospirosis, formolised cultures of $L$. icterohaemorrhagiae and $L$. canicola being employed as antigens in microscopic agglutination tests. It is usual to try and demonstrate a rise in antibody titre in two or more blood samples taken at intervals of about seven to 10 days.

The findings in the present investigation suggest that these restricted agglutination tests, using only two leptospiral antigens, will in fact detect many cases of acute leptospirosis, whatever the infecting serotype, because of the degree of co-agglutination usually present. However, the infecting serotype may sometimes not be correctly identified; more importantly, if co-agglutination is not marked and infection is due to some other serotype, a completely negative result may be obtained. It would obviously be preferable to use diagnostic methods which will detect infection by all leptospiral serotypes; for routine use in diagnostic laboratories any such tests employed must be reasonably simple, yet reliable.

Detailed descriptions of many of the available techniques are given by Alston and Broom (1958) and Babudieri (1961), and they have been critically reviewed by Gochenour, Gleiser, and Ward (1958). More recently, an international group of experts on leptospirosis have stated current opinion on various diagnostic procedures (Memorandum, 1965). Some techniques are not suitable for ordinary laboratory use; for instance, many of the serological reactions 
are serotype-specific, and therefore require the use of multiple antigens in order to detect all possible leptospiral antibodies, as was attempted in the present investigation; these procedures are very laborious and time-consuming. Macroscopic agglutination tests, such as that of Galton, Powers, Hall, and Cornell (1958), may partly solve these difficulties, but a more promising approach appears to be the use of a genus-specific reaction, e.g., the sensitized erythrocyte lysis test (Cox, 1957), the sensitized erythrocyte agglutination test (McComb, Smith, Coffin, MacCready, and Chang, 1957), or certain complement-fixation methods (Randall, Wetmore, and Warner, 1949; Elian and Nicoara, 1964).

It is important that we should obtain a more complete picture of the true frequency and nature of these leptospiral infections, both from the epidemiological point of view and from that of the individual patient. This implies more accurate diagnosis, particularly in the atypical infections, and it is suggested that this might most conveniently be achieved in two ways:

1 By more frequent attempts to isolate leptospirae, particularly from acute-phase blood samples from patients with febrile illnesses: isolates may be obtained by inoculating a small volume of blood into (a) leptospiral culture media (e.g., Korthof's or Stuart's media) or (b) suitable laboratory animals.

Later in the illness leptospirae can sometimes be isolated by similar means from cerebrospinal fluid or from urine. Isolation of organisms is very desirable, as it enables the infecting strain to be accurately identified and typed. Method $(a)$ is easy to carry out and gives good results (Babudieri, 1961), provided that blood samples are taken during the first few days of illness. However, there is at present a tendency towards the empirical use of antibiotics in undiagnosed pyrexial illnesses, and leptospirae are sensitive to many of these drugs. It is therefore important that, where possible, specimens for isolation of leptospirae (or indeed any other pathogenic bacteria) should be obtained before antibiotics are given.

2 By the use of a genus-specific reaction to test for leptospiral antibodies: a complement-fixation test is being evaluated at present in Britain (Turner, 1965). If it proves satisfactory, it would fulfil the need for a simple method of screening sera for evidence of active leptospirosis, using a technique already employed in many laboratories.

The adoption of more comprehensive procedures such as these would help to reveal to what extent, if any, we are failing to diagnose leptospirosis by our present methods. However, an equally important aspect of the diagnosis of these infections is that physicians and bacteriologists should be aware of their diverse clinical manifestations, and that they should consider the possibility of leptospirosis in patients who may present with pyrexia of unknown origin only.

\section{CONCLUSIONS}

We can no longer assume that human leptospirosis in the British Isles only involves the two familiar serotypes, $L$. icterohaemorrhagiae and $L$. canicola. Two additional serotypes, $L$. ballum and $L$. bratislava, are causing human infections in Northern Ireland, and others will almost certainly be incriminated in due course.

It is probable that many of these leptospiral infections are relatively mild, perhaps 'influenzal' in character, but further work is needed to clarify the situation. Meanwhile, the possibility of leptospirosis should be considered in all obscure pyrexial illnesses, particularly if there is meningeal involvement. This applies especially to such illnesses in farmers and others who are in contact with animals, either wild or domestic. Appropriate laboratory investigations should be undertaken in such cases, including attempts to isolate leptospirae from blood during the early stages of the illness, thus allowing accurate typing of infecting strains.

There is also a need for a simple but reliable screening test for the serological diagnosis of all types of leptospiral infection. Until one becomes available the agglutination test with a restricted number of antigens will probably remain in general use. However, the possible inadequacies of this test should be remembered, and, where negative or equivocal results are obtained on patients with strong clinical suspicion of leptospirosis, the sera should be sent to a reference laboratory for more complete examination with a wider range of leptospiral antigens.

I am indebted to Dr. L. H. Turner of the Leptospirosis Reference Laboratory, Wellcome Laboratories of Tropical Medicine, ${ }^{1}$ London, for suggesting this investigation, for his valuable help and advice during it, for supplying the leptospiral strains and their antisera, and for checking most of the positive serological findings.

I wish to thank Dr. V. D. Allison, Dr. J. E. Morison, and Dr. C. C. Kennedy for encouragement during this work; Mr. N. McDonald for help in the preparation of media and in the maintenance of the leptospiral cultures; and Dr. J. H. Connolly for providing sera from patients with aseptic meningitis. I am grateful to many hospital physicians and general practitioners throughout Northern Ireland for giving me clinical details regarding their patients and for obtaining additional blood samples for testing.

1This reference laboratory, one of those recognized by WHO/FAO, has now become part of the Public Health Laboratory Service and is accommodated at the London School of Hygiene and Tropical Medicine, W.C.1. 


\section{REFERENCES}

Alexander, A. D., Gleiser, C. A., Malnati, P., and Yoder, H. (1957). Amer. J. Hyg., 65, 43.

Alston, J. M., and Broom, J. C. (1958). Leptospirosis in Man and Animals. Livingstone, Edinburgh and London.

Baber, M. D., and Stuart, R. D. (1946). Lancet, 2, 594.

Babudieri, B. (1961). Bull. Wld Hlth Org., 24, 45.

Boak, R. A., Linscott, W. D., and Bodfish, R. E. (1960). Calif. Med., 93, 163.

Borg-Petersen, C. (1944). Acta path. microbiol. scand., 21, 504.

Broom, J. C. (1951). Brit. med. J., 2, 689.

- , and Coghlan, J. D. (1958). Lancet, 2, 1041.

- and - (1960). Ibid., 1, 1326. and MacIntyre, A. B. (1948). Vet. Rec., 60, 487.

Coghlan, J. D., Norval, J., and Seiler, H. E. (1957). Brit. med. J., $1,257$.

Covaleda, J., Pumarola, A., and Cantarell, I. (1953). Rev. ibér. Parasit., 13, 289.

Cox, C. D. (1957). J. infect. Dis., 101, 203.

Davies, M. E. (1957). Vet. Rec., 69, 93. (1960). J. Hyg. (Lond.), 58, 243.

Elian, M., and Nicoará, I. (1964). Bull. Wld Hlth Org., 31, 359.

Fühner, F. (1951). Z. Immun.-Forsch., 108, 278.

Galton, M. M., Powers, D. K., Hall, A. D., and Cornell, R. G. (1958)• Amer. J. vet. Res., 19, 505.

Gochenour, W. S., Jr., Gleiser, C. A., and Ward, M. K. (1958). Ann. N.Y. Acad. Sci., 70, 421.

Humphreys, F. A., Campbell, A. G., and Smith, E. S. (1953). Canad. J. comp. Med., 17, 206.
Kappeler, R., Barandun, S., Lüthi, H., and Wiesmann, E. (1961). Schweiz. med. Wschr., 91, 810.

Kennedy, C. C. (1954). D.M. Thesis, Oxford.

Kmety, E. (1954). Cs. Epidem., 3, 41 (absta., Bull. Hyg. (Lond.), 1954, 29, 734).

(1960). J. Hyg. Epidem. (Praha), 4, 171.

McComb, D. E., Smith, D. J. W., Coffin, D. L., MacCready, R. A. and Chang, R. S. (1957). Amer. J. trop. Med. Hyg., 6, 90

Manson-Bahr, P., Wenyon, C. M., and Brown, H. C. (1922). Lancet, 2, 1056.

Memorandum (1965). Bull. Wld Hlth Org., 32, 881.

Michna, S. W. (1958). Vet. Rec., 70, 80.

Plesko, I., Bakoss, P., Kmety, E., and Vachold, J. (1960). Cs. Epidem. 9, 12 (abstr. Bull. Hyg. (Lond.), 1960, 35, 582).

Randall, R., Wetmore, P. W., and Warner, A. R., Jr. (1949). J. Lab. clin. Med., 34, 1411.

Report (1956). Wld Hlth Org. techn. Rep. Ser., 113.

Report (1959). Ibid., 169.

Schüffner, W. (1934). Trans. roy. Soc. trop. Med. Hyg., 28, 7.

Slavin, G., Salt, G. F. H., and Wolff, J. W. (1964). Nature (Lond.), 203, 893.

Smith, D. J. W., and Brown, H. E. (1955). Aust. Ann. Med., 4, 287.

Stoenner, H. G., and Maclean, D. (1958). Arch. intern. Med., 101, 606.

Turner, L. H. $(1962,1963,1965)$. Personal communications.

Walch-Sorgdrager, B. (1939). Bull. Hlth Org. L. of N., 8, 143.

Weil, A. (1886). Dtsch. Arch. klin. Med., 39, 209.

Wolff, J. W. (1954). The Laboratory Diagnosis of Leptospirosis. Thomas, Springfield, Illinois.

-, and Broom, J. C. (1954). Docum. Med. geogr. trop. (Amst.), 6, 78.

Yager, R. H., Gochenour, W. S., Jr., Alexander, A. D., and Wetmore, P. W. (1953). Proc. Soc. exp. Biol. (N.Y.), 84, 589. 